\title{
Comprehensive investigation of the prevalence and risk factors of viral hepatitis $B$ and $C$ in PERSIAN Guilan Cohort Study
}

Farahnaz Joukar

Guilan University of Medical Sciences

Mohammadreza Naghipour

Guilan University of Medical Sciences

Soheil Hassanipour

Guilan University of Medical Sciences

Sara Yeganeh

Guilan University of Medical Sciences

Soheil Soltanipour

Guilan University of Medical Sciences

Ali Akbar Samadani

Guilan University of Medical Sciences

Ezzat Paryad

Guilan University of Medical Sciences

Masood Sepehrimanesh

Guilan University of Medical Sciences

Afshin Shafaghi

Guilan University of Medical Sciences

Fariborz Mansour-Ghanaei ( $\sim$ fmansourghanaei@gmail.com )

Guilan University of Medical Sciences

Research article

Keywords: HBV, HCV, PERSIAN cohort, prevalence

Posted Date: September 8th, 2019

DOI: https://doi.org/10.21203/rs.2.14159/v1

License: (1) (1) This work is licensed under a Creative Commons Attribution 4.0 International License.

Read Full License 


\section{Abstract}

Background Hepatitis B (HBV) and C (HCV) viruses are two serious infectious diseases with high global health impact. The aim of this study was to evaluate the prevalence of HBV and HCV in the Prospective Epidemiological Research Studies of the Iranian Adults (PERSIAN) Guilan Cohort Study through immunological and molecular methods.

Methods The blood samples were obtained from 10520 enrolled participant. Complete biochemical and hematological assessments plus urine analysis were done. The presence of $\mathrm{HBsAg}$, anti-HBs, anti-HBc and anti-HCV antibodies for all participants and HBeAg and anti-HBe antibody for HBV positive patients were evaluated. HBV genomic DNA and HCV genomic RNA were extracted from positive serum samples. Real time PCR assay was done to quantify HBV and HCV genomes. HCV genotyping was also performed.

Results Most of our participants were female (53.5\%), rural (56.1\%), married (97.2\%) with primary education $(72.1 \%)$ without smoking $(75.2 \%)$ or alcohol consumption (85.3\%). The HBV and HCV prevalence was $0.24 \%(95 \% \mathrm{Cl}, 0.16 \%$ to $0.35 \%)$ and $0.11 \%(95 \% \mathrm{Cl}, 0.06 \%$ to $0.19 \%)$, respectively. Rural participants were significantly more HBV positive than urban peoples $(P=0.045)$ while male individuals were significantly more HCV positive than female participants $(P=0.013)$.

Conclusion Our detected HBV and HCV prevalence were lower than other cities/provinces of Iran, which may be due to the lifestyle or other unknown reasons.

\section{Background}

The hepatitis $B$ virus (HBV) is a viral agent whose target tissue is liver and can cause both acute and chronic illnesses [1]. According to the 2016 World Health Organization (WHO) statistics, 240 million people who are positive for at least 6 months of HBsAg are reported as HBV positive individuals [2]. Meaningly, more than 686,000 people die each year due to the effects of the virus, including cirrhosis and cancer [3]. Finally, the highest rates of hepatitis B are found in Africa and East Asia [4-7].

The hepatitis $\mathrm{C}$ virus (HCV) is the main cause of chronic liver disease, which can lead to chronic hepatocellular carcinoma with high economic burden [8-11]. It has silent epidemiology and at the same time is a major blood-borne infection worldwide [12]. According to the latest global health statistics, 130150 million people are infected with HCV [13] and 700,000 people die each year [14]. HCV has seven genotypes and 70 subtypes. HCV RNA assays are the most sensitive test for HCV infection and are a gold standard for proving hepatitis $C$ infection [15]. Between 1990 and 2013, global viral hepatitis deaths increased from 0.89 million (95\% uncertainty interval [UI] 0.86-0.94) to 1.45 million (1.38-1.54) [16]. Base on one modeling study in 2016, the global prevalence of HBsAg was 3.9\% (95\% uncertainty interval [UI] 3-4-4·6) [17].

Therefore, Iran is classified as low to intermediate prevalence areas [18]. The last updated meta-analysis about HBV prevalence in Iran, show that among general population approximately $2.2 \%$ in 2016 [19]. 
Although certain population sub-groups such as hemophiliacs and hemodialysis are more susceptible to HBV and HCV [20-25], but evaluation of the prevalence of these two viruses in general population also is very important. Considering the importance of hepatitis $B$ and $C$ in this study, the prevalence of these viruses in people referring to the cohort of Guilan province will be discussed.

\section{Methods}

\section{Participants}

This study is nested in the Guilan center of Prospective Epidemiological Research Studies of the Iranian Adults (PERSIAN) cohort study [26, 27], which named PERSIAN Guilan Cohort Study (PGCS). The PGCS was started at September 2014 in Some'e Sara (GPS coordinator Latitude: 37.308003 \& Longitude: 49.315022), Guilan, Northern of Iran. All residents between 35 to 70 years were enrolled. These 10520 peoples will be followed at least for 10 years to understand new diseases and identify the underlying genetic susceptibility factors for chronic diseases. Moreover, participants were followed up yearly by telephone or medias and they were encouraged to participate in the study. Peoples who were unable to attend the clinic for examination or refusal by a person to participate in the study were excluded [28].

\section{Sampling and biochemical assessments}

The aseptic blood samples were collected from the cubical vein into vacutainers. Total number of WBC, RBC, platelet, lymphocyte, monocyte, and granulocytes were counted. The serum sample was harvested and stored at $-20^{\circ} \mathrm{C}$ until use for complete biochemical assessment. The $\mathrm{Hb}$ concentration and level of Hct, MCV, MCH, MCHC, RDWCV, RDWSD, plateletcrit, MPV, PDW were also evaluated. Urine sample was collected and used immediately for measuring of specific gravity (SG), $\mathrm{pH}$, and creatinine level.

\section{Virological assessments}

The presence of HBsAg, anti-HBs, anti-HBc and anti-HCV antibodies were determined by Electrochemiluminescence (Cobas e 411, Roche, Germany). For positive patients, these four tests plus presence of $\mathrm{HBeAg}$ and anti-HBe antibody were measured again. HBV genomic DNA was extracted from positive serum samples by viral DNA extraction kit (QIAGEN, Germany). HCV genomic RNA was extracted from positive serum samples by viral RNA extraction kit (Roche, Germany). To quantify HBV and HCV genomes, qPCR assay was carried out using TaqMan-based commercial available kit (QIAGEN, Germany) based on the manufacturer's instructions. HCV genotyping was done using HCV Genotype Plus Real-TM kit (Sacase Biotechnologies, Italy). 
This study was confirmed by the Ethics Committee of Guilan University of Medical Sciences (Ethics code: IR.GUMS.REC. 1396.254).

\section{Statistical analysis}

Qualitative data were expressed as frequency and percentage and their association with HBV and HCV statuses were analyzed using Chi square test. Quantitative data were presented as mean \pm SD and between HCV/HBV positive and negative groups differences were analyzed using two independent sample t test. All statistical analysis were performed using SPSS version 23 . The P value lesser than 0.05 was considered as significant difference.

\section{Results}

Demographic characteristics of our patients and statuses of HBV and HCV infection are presented in Table 1. Most of our participants were female (53.5\%), rural (56.1\%), married (97.2\%) with primary education (< 12 years) $(72.1 \%)$ without smoking $(75.2 \%)$ or alcohol consumption (85.3\%). In addition, most of them had history of surgery (63.3\%) and hospitalization (80.6\%) and had no transfusion (89.5\%) or genital aphthous (98.8\%). The HBV prevalence was $0.24 \%(95 \% \mathrm{Cl}, 0.16 \%$ to $0.36 \%)$ and the HCV prevalence was $0.11 \%(95 \% \mathrm{Cl}, 0.06 \%$ to $0.19 \%)$. The geographic distribution of HBV positive and HCV positive patients based on gender are presented in Figure 1. Rural participants were significantly more HBV positive than urban peoples $(P=0.045)$ while male individuals were significantly more HCV positive than female participants $(P=0.013)$. No other significant associations were detected between other evaluated demographic variables with HBV and HCV prevalence.

The complete blood and urine analysis of our participants are presented in Table 2. HBV positive patients had significant lower platelet count $(P=0.043)$, RDWCV $(P=0.023)$, cholesterol $(P=0.033), L D L(P=0.043)$ and LDL: HDL ratio $(P=0.002)$ compared to HBV negative participants. HCV positive patients had significant higher $\mathrm{MCH}(P=0.036), \mathrm{MCHC}(P=0.047)$, AST $(P=0.032)$, ALT $(P=0.030)$ and HDL $(P=0.039)$ and significant lower LDL $(P=0.028)$ and $L D L$ : HDL ratio $(P=0.001)$ compared to HCV negative individuals.

The viral load of $25 \mathrm{HBV}$ positive and $12 \mathrm{HCV}$ positive patients are presented in Table 3. Most HBV positive patients (52\%) had lesser than 300 copies of HBV DNA per ml. While, most HCV positive patients 
(58.4\%) had $10^{5}-10^{6}$ copies of HCV RNA per ml. Most detected HCV genotype was 2a (Figure 2). Firstdegree relatives of all HCV positive patients were also checked for HCV infection by qPCR. Just child of one patients had HCV infection with genotype similar to her mother as $1 \mathrm{a}$.

\section{Discussion}

In the present study, the prevalence of HBV and HCV in the Guilan site of PERSIAN cohort were reported. We found the prevalence of 0.2 and 0.1 for HBV and HCV, respectively. Moreover, rural participants were significantly more HBV positive while male individuals were significantly more HCV positive. Finally, HBV positive patients had significant lower platelet count, RDWCV, cholesterol, LDL and LDL: HDL ratio and HCV positive patients had significant higher $M C H, M C H C, A S T, A L T$ and HDL and significant lower LDL and LDL:HDL ratio compared to related negative individuals.

The prevalence of HBV and HCV is very difference worldwide, which is related to geographical region and demographic factors. In 2015, it has been reported that HBV sero-prevalence was $8.83 \%(0.48-22.38)$ in African region, $0.81 \%$ (0.20 - 13.55) in Americas region, 3.01\% (0.67 - 14.77) in Eastern Mediterranean region, $2.06 \%$ (0.01 - 10.32) in European region, 1.90\% (0.82 - 6.42) in South East Asian region, 5.26\% (0.37 - 22.70) in Western Pacific region [4]. In addition, there are several diversity in HBV prevalence between different states/provinces of each country. Since 2006 when the national vaccination program for peoples who born after 1993 were started and continued, an obvious decrease in the HBV prevalence was seen [29]. Therefore, Iran is classified as low to intermediate prevalence areas [18]. Although our detected rate of HBV infection is too lower than reported pooled HBV prevalence in Iran among general population (2.2\%) in 2016 [19], it is approximately similar to our previous report about volunteer blood donors as $0.45-0.48 \%$ [30, 31] and to reported rates from Karaj as $0.4 \%$ [32], Kermanshah as $0.7 \%$ [33] and Kurdistan as $0.8 \%$ [34]. Also, our reported HBV infection rate is lower than those reported from Birjand as $1.6 \%$ [35], Tehran, Golestan, and Hormozgan as $2.6 \%$ [36], and Nahavand as $2.3 \%$ [37]. In addition, some population sub-groups are more likely susceptible to have HBV. For instances in our province, $71.3 \%$ of hemophiliacs [22], and $0.38-3.8 \%$ of hemodialysis patients [20,21,23] were HBV positive. We found that men are more HBV positive than women (16 vs. 9 cases) which is similar to previous reports from Iran about higher prevalence of HBV infection in men $[19,38]$.

The pooled HCV prevalence of $0.3 \%, 6.2 \%$, and $32.1 \%$ were reported for general, intermediate- and highrisk Iranian populations, respectively [39]. Again, diversities between different cities/provinces and subgroups are seen. It has been reported that all healthy adults of Isfahan [40] and Mashhad [41], blood donors of Tehran [42], Ardabil [43], and Ahvaz [44], infertile male of Tehran [45], and male blood donor of Tabriz [46] were HCV negative. Our detected HCV prevalence $(0.1 \%)$ is lower than pooled HCV prevalence of Iranian general population as $0.3 \%$ [39] and is differed from previous report from Rasht as $0.03 \%$ and Guilan as $0.32 \%$ [47]. Also, our detected HCV prevalence is lower than other reported prevalence from Northern provinces of Iran. For instance, HCV prevalence was $0.48 \%$ in Babol [48], and $0.18-1 \%$ in Golestan [49-51]. However, Zamani et al. reported similar HCV prevalence as $0.08 \%$ in general population of Mazandaran province [52]. Higher male HCV positivity, as seen in our study, was also reported 
previously from Kerman province [53], Zahedan [54], and Kavar [55]. However, in opposite to our study, Ghadir et al. reported that female were more HCV positive compared to male in general population of Golestan [49]. Finding of one woman who her daughter also was HCV positive and both had same HCV genotype highlighted the clear role of interfamilial HCV transmission and confirmed the significant role of close relatives which reported previously [56].

Although, we detected no significant associations between demographic variables and prevalence of HBV and HCV, but it seems that different demographic features of population in different regions are the most important reasons for these differences in HBV and HCV prevalence. Base on Baig's study the male to female ratio of $\mathrm{HBV}$ increased during the reproductive years. There may be an influence of estrogen in the protection and defense of hepatic cells against the development of chronic liver disease [57]. In Zeng et.al study married people had the highest prevalence of HBsAg [58], on the other hand in Ataei et.al study in Isfahan province no statistical difference observed in terms of marital status but males $(O R=3.79)$ had higher prevalence of HBV than women [59].

About biochemical analysis, we found some significant differences. Among them, decrease of LDL and subsequently LDL: HDL ratio in both HBV and HCV positive patients compared to negative ones are interesting. These are in line with those reported recently as significant hypolipidemia in HBV [60] and HCV [61] patients. Lower platelet count in HBV positive, as we found in this study, also reported previously [62]. It can be said that, both HBV and HCV influenced the liver tissue and the changes in biochemical and hematological parameters can be related to these changes in the hepatic functions.

\section{Conclusions}

In summary, we found lower HBV and HCV prevalence compared to other regions of Iran. Also, compared to previous reports from our province, Guilan, the HBV and HCV prevalence also decreased. This may be due to the preventive strategy or increase of the medical knowledge of peoples, which must be evaluated in the further studies.

\section{Abbreviations}

HBV: Hepatitis B Virus, HCV: Hepatitis C Virus, HBcAg: Hepatitis Core Antigen, HBsAg: Hepatitis B Surface Antigen

\section{Declarations}

\section{Acknowledgments}

Authors wish to thank all staffs of Guilan center of Prospective Epidemiological Research Studies of the Iranian Adults (PERSIAN) cohort study for their kindly help in data collection. 


\section{Author contributions}

Study conception and design: F.J, A.SH and F.M

Acquisition of data: M, S, AA.S, A.S and S.Y

Statistical analysis: M.N, S.S, M.S and S.H

Interpretation of results: F.J, F.M, EP and S.H

Drafting of manuscript: F.J, S.Y, A.S and S.H

All authors approved the final version of the article, including the authorship list

\section{Availability of data and materials}

The datasets analyzed during the current study are available from the corresponding author on reasonable request.

\section{Funding}

A substantial part of this study was supported by the Research Council of Guilan University of Medical Sciences

\section{Ethics approval and consent to participate}

Ethical approval of the study was obtained from Guilan University of Medical Sciences. (Grant number: 1397.163). Written consent was taken after informing the purpose and importance of the study to each participant. To ensure confidentiality of participant's information, codes were used where by the name of the participant and any identifier of participants was not written on the questionnaire.

\section{Consent for publication}

Not applicable. 
Competing interests

The authors declare that they have no competing interests.

\section{References}

1. Rahimi R, Hosseini SY, Fattahi MR, Sepehrimanesh M, Safarpour A, Malekhosseini SA, Nejabat M, Khodadad M, Ardebili M: YMDD Motif Mutation Profile Among Patients Receiving Liver Transplant Due to Hepatitis B Virus Infection With Long Term Lamivudine/Immunoglobulin Therapy. Hepatitis Monthly 2015, 15(7):e27120.

2. Hepatitis B [http://www.who.int/news-room/fact-sheets/detail/hepatitis-b]

3. Qin Y, Zhong Y, Ma T, Zhang J, Yang G, Guan F, Li Z, Li B: A pilot study of salivary N-glycome in HBVinduced chronic hepatitis, cirrhosis, and hepatocellular carcinoma. Glycoconjugate journal 2017, 34(4):523-535.

4. Schweitzer A, Horn J, Mikolajczyk RT, Krause G, Ott JJ: Estimations of worldwide prevalence of chronic hepatitis B virus infection: a systematic review of data published between 1965 and 2013. Lancet (London, England) 2015, 386(10003):1546-1555.

5. Aniaku JK, Amedonu EK, Fusheini A: Assessment of knowledge, attitude and vaccination status of hepatitis B among nursing training students in ho, ghana. Annals of global health 2019, 85(1).

6. Tanga AT, Teshome MA, Hiko D, Fikru C, Jilo GK: Sero-prevalence of hepatitis B virus and associated factors among pregnant women in Gambella hospital, South Western Ethiopia: facility based crosssectional study. BMC infectious diseases 2019, 19(1):602.

7. Makuza JD, Rwema JOT, Ntihabose CK, Dushimiyimana D, Umutesi J, Nisingizwe MP, Serumondo J, Semakula M, Riedel DJ, Nsanzimana S: Prevalence of hepatitis B surface antigen (HBsAg) positivity and its associated factors in Rwanda. BMC infectious diseases 2019, 19(1):381-381.

8. Zare F, Fattahi MR, Sepehrimanesh M, Safarpour AR: Economic Burden of Hepatitis C Virus Infection in Different Stages of Disease: A Report From Southern Iran. Hepatitis Monthly 2016, 16(4):e32654.

9. Hassanipour S, Mohammadzadeh M, Mansour-Ghanaei F, Fathalipour M, Joukar F, Salehiniya H, Abdzadeh E, Samadani AA, Nikbakht H-A, Arab-Zozani M: The Incidence of Hepatocellular Carcinoma in Iran from 1996 to 2016: a Systematic Review and Meta-analysis. Journal of Gastrointestinal Cancer 2019, 50(2):193-200.

10. Njouom R, Siffert I, Texier G, Lachenal G, Tejiokem MC, Pépin J, Fontanet A: The burden of hepatitis C virus in Cameroon: Spatial epidemiology and historical perspective. Journal of viral hepatitis 2018, 25(8):959-968.

11. Lembo T, Saffioti F, Chiofalo B, Granese R, Filomia R, Grasso R, Triolo O, Raimondo G: Low prevalence of hepatitis $B$ and hepatitis $C$ virus serum markers in a cohort of pregnant women from Southern Italy. Digestive and Liver Disease 2017, 49(12):1368-1372. 
12. Afshari R, Fattahi M, Sepehrimanesh M, Safarpour AR, Nejabat M, Dehghani SM, Shamsdin SA: The Seroepidemiology of Hepatitis C Infection in Drug Abusers Referring to Shiraz Drug Rehabilitation Centers. Govaresh 2016, 21(3):188-192.

13. Pawlotsky J-M, Aghemo A, Back D, Dusheiko G, Forns X, Puoti M, Sarrazin C: EASL recommendations on treatment of hepatitis C 2015. J hepatol 2015, 63(1):199-236.

14. Lozano R, Naghavi M, Foreman K, Lim S, Shibuya K, Aboyans V, Abraham J, Adair T, Aggarwal R, Ahn SY: Global and regional mortality from 235 causes of death for 20 age groups in 1990 and 2010: a systematic analysis for the Global Burden of Disease Study 2010. The lancet 2012, 380(9859):20952128.

15. Wilson EM, Rosenthal ES, Kattakuzhy S, Tang L, Kottilil S: Clinical laboratory testing in the era of directly acting antiviral therapies for hepatitis C. Clinical microbiology reviews 2017, 30(1):23-42.

16. Stanaway JD, Flaxman AD, Naghavi M, Fitzmaurice C, Vos T, Abubakar I, Abu-Raddad LJ, Assadi R, Bhala N, Cowie B et al: The global burden of viral hepatitis from 1990 to 2013: findings from the Global Burden of Disease Study 2013. Lancet 2016, 388(10049):1081-1088.

17. Global prevalence, treatment, and prevention of hepatitis B virus infection in 2016: a modelling study. The lancet Gastroenterology \& hepatology 2018, 3(6):383-403.

18. Ott JJ, Stevens GA, Groeger J, Wiersma ST: Global epidemiology of hepatitis B virus infection: new estimates of age-specific HBsAg seroprevalence and endemicity. Vaccine 2012, 30(12):2212-2219.

19. Salehi-Vaziri M, Sadeghi F, Almasi Hashiani A, Gholami Fesharaki M, Alavian SM: Hepatitis B Virus Infection in the General Population of Iran: An Updated Systematic Review and Meta-Analysis. Hepatitis Monthly 2016, 16(4):e35577.

20. Farahnaz J, Sepiedeh B, Hasan M, Fariborz M-G: Hepatitis C and hepatitis B seroprevalence and associated risk factors in hemodialysis patients in Guilan province, north of Iran. Hepatitis Monthly 2011, 2011(3, Mar):178-181.

21. Khamesipour A, Amiri ZM, Kafiabad SA, Saadat F, Mansour-ghanaei F, Esteghamati A-R, Shakib RJ: Frequency of hepatitis B virus DNA in anti-HBc positive, HBsAg negative blood donors in Rasht, northern Iran. Transfusion and Apheresis Science 2011, 45(2):195-197.

22. Mansour-Ghanaei F, Fallah M-S, Shafaghi A, Yousefi-Mashhoor M, Ramezani N, Farzaneh F, Nassiri R: Prevalence of hepatitis $B$ and $C$ seromarkers and abnormal liver function tests among hemophiliacs in Guilan (northern province of Iran). Medical Science Monitor 2002, 8(12):CR797-CR800.

23. Mansour-Ghanaei F, Sadeghi A, Mashhour MY, Joukar F, Besharati S, Roshan ZA, Khosh-Sorur M: Prevalence of hepatitis B and C infection in hemodialysis patients of Rasht (Center of Guilan Province, Northern Part of Iran). Hepat Mon 2009, 9(1):45-49.

24. Shamsdin S, Sepehrimanesh M, Pezeshki B, Nejabat M: Seroprevalence of hepatitis B and C in patients with hemophilia: A single-centre descriptive study. Shiraz E-Medical Journal 2015, 16(7):e24573.

25. Joukar F, Mansour-Ghanaei F, Naghipour MR, Hassanipour S: Knowledge, distribution and risk factors of hepatitis B and C infection in high-risk groups in Guilan province, Iran. Hepatitis Monthly 
2018, 18(8).

26. Poustchi H, Eghtesad S, Kamangar F, Etemadi A, Keshtkar A-A, Hekmatdoost A, Mohammadi Z, Mahmoudi Z, Shayanrad A, Roozafzai F: Prospective Epidemiological Research Studies in Iran (the PERSIAN Cohort Study): Rationale, Objectives, and Design. American Journal of Epidemiology 2017, 187(4):647-655.

27. Mansour-Ghanaei F, Joukar F, Naghipour MR, Sepanlou SG, Poustchi H, Mojtahedi K, Balou HA, Heidarzadeh A, Malekzadeh R: The PERSIAN Guilan Cohort Study (PGCS). Archives of Iranian medicine 2019, 22(1):39-45.

28. Mansour GF, Joukar F, Naghipour A, Poustchi H, Mojtahedi K, Balou H, Malekzadeh R: Cohort profile: The PERSIAN Guilan Cohort Study (PGCS). Journal of Epidemiology and Community Health 2018, Submitted.

29. Mohaghegh Shelmani H, Karayiannis P, Ashtari S, Mahmanzar MA, Khanabadi B, Modami N, Gholipour F, Zare F, Zali MR: Demographic changes of hepatitis B virus infection in Iran for the last two decades. Gastroenterology and Hepatology From Bed to Bench 2017, 10(Suppl1):S38-S43.

30. FariborzMansour G, MohammadSadegh F, Reyhaneh J, Farahnaz J, Afshin S, Ramin T: Prevalence of hepatitis $B$ surface antigen and hepatitis $C$ virus antibody and their risk factors among Guilan's volunteer blood donors (1998-2003). Hepatitis Monthly 2007, 2007(4, Autumn):239-241.

31. Mansour-Ghanaei F, Falah MS, Jafarshad R, Joukar F, Salari A, Tavaf ZR, Khoush SM: Prevalence of hepatitis B and hepatitis C, and their risk factors among Guilan blood donors. The Scientific Journal of Iranian Blood Transfusion Organization (Khoon) 2008, 5:331-336.

32. Kabir K, Hoseini H, Miri M, Amrollahi F, Bahraini E, Afrogh P, Kalantar E: Prevalence of chronic viral hepatitis infections in Karaj, Iran. The Pan African medical journal 2017, 28:186.

33. Alavian SM, Tabatabaei SV, Nourizad S, Mansouri F, Khademi N, Kafi-abad SA, Gharehbaghian A, Abolghasemi H: Seroepidemiology of HBV Infection in Kermanshah-West of Iran; a Population Based Study. Jundishapur Journal of Microbiology 2012, 5(4):564.

34. Alavian SM, Tabatabaei SV, Ghadimi T, Beedrapour F, Kafi-abad SA, Gharehbaghian A, Abolghasemi $\mathrm{H}$ : Seroprevalence of hepatitis B virus infection and its risk factors in the west of Iran: a populationbased study. International journal of preventive medicine 2012, 3(11):770.

35. Ziaee M, Ebrahimzadeh A, Azarkar Z, Namaei MH, Saburi A, Fereidouni M, Bijari B, Karamian M, Sharifzadeh G: Seroprevalence and Risk Factors for Hepatitis B in an Adult Population: The First Report from Birjand, South Khorasan, Iran. Hepat Mon 2016, 16(9):e36452.

36. Merat S, Rezvan H, Nouraie M, Jamali A, Assari S, Abolghasemi H, Radmard AR, Zaer-Rezaii H, ZeidAbadi-Nejhad M, Hosseini MR et al: The prevalence of hepatitis $B$ surface antigen and anti-hepatitis B core antibody in Iran: a population-based study. Archives of Iranian medicine 2009, 12(3):225-231.

37. Alizadeh A, Ranjbar M, Ansari S, MirArab A, Alavian S, Mohammad K, Adibi P, Sadri GH, Keramat F, Ardalan A: Seroprevalence of hepatitis B in Nahavand, Islamic Republic of Iran. Eastern Mediterranean Health Journal 2006, 12(5):528-537. 
38. Alavian SM, Hajarizadeh B, AsI MA, Kabir A, Lankarani KB: Hepatitis B virus infection in iran: a systematic review. Hepatitis Monthly 2008, 8(4):281-294.

39. Mahmud S, Akbarzadeh V, Abu-Raddad LJ: The epidemiology of hepatitis C virus in Iran: Systematic review and meta-analyses. Scientific Reports 2018, 8:150.

40. Alavian SM, Ataei B, Ebrahimi A, Pirhaji O, Azad R, Olya B, Ataei AM: Anti-hepatitis E antibody in hemodialysis patients in Isfahan, Iran: prevalence and risk factors. Hepatitis monthly 2015, 15(9).

41. Gerayli S, Meshkat Z, Pasdar A, Mozafari PM, Banihashemi E, Khajavi MA, Rasekhi J: The association between oral lichen planus and hepatitis $C$ virus infection; a report from northeast of Iran. Jundishapur journal of microbiology 2015, 8(4).

42. Amini S, Mahmoodabadi SA, Lamian S, Joulaie M, Farahani MM: Prevalence of hepatitis G virus (HGV) in high-risk groups and blood donors in Tehran, Iran. Iranian Journal of Public Health 2005, 34(4):41-46.

43. Mogaddam MR, Anamzade F: Survey of relationship between hepatitis $\mathbf{C}$ and lichen planus among dermatology outpatients of Imam Hospital of Ardabil city. Journal of Pakistan Association of Dermatology 2016, 20(1):19-22.

44. Samadi M, Ghasemzade A, Sarizade G, Ebrahimi S, Saati S, Abassinejad-Pour A, Nazari Ardekani L: The comparison of the prevalence rates of HBV, HCV, and HIV in blood donors having deferred for high risk behaviors. Scientific Journal of Iranian Blood Transfusion Organization 2014, 10(4).

45. Chamani L, Zera'ati H, Asgari S, Shabestari O, Soltan-Ghorayi H, Habibzadeh-Shoja'i A:

Seroepidemiologic study of CMV, toxoplasma and hepatitis B and C in clients of Avicenna Infertility Clinic. Iran J Infect Dis Trop Med 2007, 11(35):59-63.

46. Gachkar L, Taremi M, MAHMOODARABI S, KHERADPEZHOUH M, KHOUSHBATEN M, DEHKHODA R, TORABI S: Frequency of antibodies to hepatitis $E$ virus among male blood donors in Tabriz. 2005.

47. Mansour-Ghanaei F, Fallah MS, Jafarshad R, Joukar F, Salari A, Tavafzadeh R: Prevalence of Hepatitis B Surface Antigen and Hepatitis C Virus Antibody and Their Risk Factors among Guilan's Volunteer Blood Donors (1998-2003). Hepatitis Monthly 2007, 7(4):239-241.

48. AghaJaniPoor K., Zandieh T.: Seroepidemiological investigation of hepatitis B,C and HIV virus in safe blood donors of Babol Blood Transfusion Center. The Scientific Journal of Iranian Blood Transfusion Organization 2006, 2(7):339-341.

49. Ghadir M, Jafari E, Amiriani M, Rezvan H, Aminikafiabad S, Pourshams A: Hepatitis C in Golestan Province-Iran. Govaresh 2006, 11(3):158-162.

50. Jamali R, Khonsari M, Merat S, Khoshnia M, Jafari E, Kalhori AB, Abolghasemi H, Amini S, Maghsoudlu M, Deyhim MR: Persistent alanine aminotransferase elevation among the general Iranian population: prevalence and causes. World journal of Gastroenterology: WJG 2008, 14(18):2867.

51. Kazemi Nejad V, Azar Housh R, Molana A, Dehbashi G: Frequency of Hepatitis B virus, Hepatitis C virus and human immunodefciency virus in blood donors and patients in Gorgan Blood Transfusion Organization in 2003. Journal of Gorgan University of Medical Sciences 2005, 15:84-86. 
52. Zamani F, Sohrabi M, Poustchi H, Keyvani H, Saeedian FS, Ajdarkosh H, Khoonsari M, Hemmasi G, Moradilakeh M, Motamed N: Prevalence and risk factors of hepatitis $\mathrm{C}$ virus infection in amol city, north of iran: a population-based study (2008-2011). Hepatitis monthly 2013, 13(12).

53. Delavari $\mathrm{M}$, Tabatabaei S: Frequency of hepatitis $\mathrm{C}$ and its related factors in blood donors in Kerman in 2003. 2004.

54. Ansari-Moghaddam A, Ostovaneh MR, Mood BS, Sanei-Moghaddam E, Modabbernia A, Poustchi H: Seroprevalence of hepatitis B surface antigen and anti hepatitis $C$ antibody in zahedan city, iran: a population-based study. Hepatitis monthly 2012, 12(9).

55. Fattahi MR, Safarpour A, Sepehrimanesh M, Hosseini AsI SMK, Mohamaddoust F: The Prevalence of Hepatitis C Virus Infection and Its Related Risk Factors Among the Rural Population of Fars Province, Southern Iran. Hepatitis Monthly 2015, 15(2):e24734.

56. Lankarani KB, Ardebili M, Sepehrimanesh M, Nejabat M, Hemmati Rad MA, Hosseini SY: Evaluation of hepatitis $C$ virus intrafamilial transmission among families with one index case, a pilot study from Fars province, Iran. Gastroenterology and Hepatology From Bed to Bench 2016, 9(4):250-258.

57. Baig S: Gender disparity in infections of Hepatitis B virus. Journal of the College of Physicians and Surgeons-Pakistan : JCPSP 2009, 19(9):598-600.

58. Zeng F, Guo P, Huang Y, Xin W, Du Z, Zhu S, Deng Y, Zhang D, Hao Y: Epidemiology of hepatitis B virus infection: results from a community-based study of 0.15 million residents in South China. Scientific reports 2016, 6:36186-36186.

59. Ataei B, Alavian SM, Shahriari-Fard F, Rabiei AA, Safaei A, Rabiei A, Ataei M: A case-control study of risk factors for hepatitis B infection: A regional report among Isfahanian adults. Journal of research in medical sciences : the official journal of Isfahan University of Medical Sciences 2019, 24:22-22.

60. Arain SQ, Talpur FN, Channa NA, Ali MS, Afridi HI: Serum lipids as an indicator for the alteration of liver function in patients with hepatitis B. Lipids in health and disease 2018, 17(1):36.

61. El Sagheer G, Soliman E, Ahmad A, Hamdy L: Study of changes in lipid profile and insulin resistance in Egyptian patients with chronic hepatitis C genotype 4 in the era of DAAs. The Libyan Journal of Medicine 2018, 13(1):1435124.

62. Abdullah SM: Prevalence of Hepatitis B and C virus infection and their co-relation with hematological and hepatic parameters in subjects undergoing Premarital Screening in the Jazan Region, Kingdom of Saudi Arabia. Pakistan journal of medical sciences 2018, 34(2):316-321.

\section{Tables}

Table 1. Mean and SD of quantitative variables plus frequency and percentage of qualitative variables in total participants and based on HBV and HCV statuses. 


\begin{tabular}{|c|c|c|c|c|c|c|c|}
\hline \multirow[b]{2}{*}{ Variables } & \multirow[b]{2}{*}{ Total } & \multicolumn{3}{|l|}{ HBV } & \multicolumn{2}{|l|}{$\mathrm{HCV}$} & \multirow[b]{2}{*}{$\begin{array}{l}P \\
\text { value }\end{array}$} \\
\hline & & Positive & Negative & $\begin{array}{l}P \\
\text { value }\end{array}$ & Positive & Negative & \\
\hline Age (year) & $51.52 \pm 8.90$ & $54.48 \pm 9.04$ & $51.51 \pm 8.90$ & 0.095 & $54.08 \pm 10.79$ & $51.51 \pm 8.89$ & 0.317 \\
\hline BMI $\left(\mathrm{kg} / \mathrm{m}^{2}\right)$ & $28.15 \pm 5.82$ & $26.32 \pm 4.00$ & $28.16 \pm 5.82$ & 0.114 & $26.49 \pm 3.66$ & $28.16 \pm 5.83$ & 0.323 \\
\hline Gender & & & & 0.078 & & & 0.013 \\
\hline Male & $\begin{array}{l}4887 \\
(46.5)\end{array}$ & $16(0.3)$ & $\begin{array}{l}4871 \\
(99.7)\end{array}$ & & $9(0.2)$ & $\begin{array}{l}4878 \\
(99.8)\end{array}$ & \\
\hline Female & $\begin{array}{l}5633 \\
(53.5)\end{array}$ & $9(0.2)$ & $\begin{array}{l}5624 \\
(99.8)\end{array}$ & & $3(0.1)$ & $\begin{array}{l}5630 \\
(99.9)\end{array}$ & \\
\hline Habitat & & & & 0.045 & & & 0.108 \\
\hline Urban & $\begin{array}{l}4619 \\
(43.9)\end{array}$ & $6(0.1)$ & $\begin{array}{l}4613 \\
(99.9)\end{array}$ & & $7(0.1)$ & 4612 99.9) & \\
\hline Rural & $\begin{array}{l}5901 \\
(56.1)\end{array}$ & $19(0.3)$ & $\begin{array}{l}5882 \\
(99.7)\end{array}$ & & $5(0.1)$ & $\begin{array}{l}5896 \\
(99.9)\end{array}$ & \\
\hline Marital status & & & & 0.490 & & & 0.647 \\
\hline Married & $\begin{array}{l}10224 \\
(97.2)\end{array}$ & $25(0.2)$ & $\begin{array}{l}10199 \\
(99.8)\end{array}$ & & $12(0.1)$ & $\begin{array}{l}10212 \\
(99.9)\end{array}$ & \\
\hline Single & $296(2.8)$ & $0(0)$ & $296(100)$ & & $0(0)$ & $296(100)$ & \\
\hline $\begin{array}{l}\text { Education } \\
\qquad \begin{array}{l}\text { Primary }(<12 \\
\text { years })\end{array}\end{array}$ & $\begin{array}{l}7590 \\
(72.1)\end{array}$ & $21(0.3)$ & $\begin{array}{l}7569 \\
(99.7)\end{array}$ & 0.301 & $10(0.1)$ & $\begin{array}{l}7580 \\
(99.9)\end{array}$ & 0.673 \\
\hline $\begin{array}{l}\text { Diploma } \\
\text { years })\end{array}$ & $\begin{array}{l}2284 \\
(21.7)\end{array}$ & $4(0.2)$ & $\begin{array}{l}2280 \\
(99.8)\end{array}$ & & $2(0.1)$ & $\begin{array}{l}2282 \\
(99.9)\end{array}$ & \\
\hline $\begin{array}{l}\text { Academic }(>12 \\
\text { years) }\end{array}$ & $646(6.1)$ & $0(0)$ & $646(100)$ & & $0(0)$ & $646(100)$ & \\
\hline Smoking & & & & 0.861 & & & 0.943 \\
\hline Yes & $\begin{array}{l}2577 \\
(24.5)\end{array}$ & $5(0.2)$ & $\begin{array}{l}2572 \\
(99.8)\end{array}$ & & $3(0.1)$ & $\begin{array}{l}2574 \\
(99.9)\end{array}$ & \\
\hline No & $\begin{array}{l}7908 \\
(75.2)\end{array}$ & $20(3)$ & $\begin{array}{l}7888 \\
(99.7)\end{array}$ & & $9(0.1)$ & $\begin{array}{l}7899 \\
(99.9)\end{array}$ & \\
\hline Not-sure & $7(0.1)$ & $0(0)$ & $7(100)$ & & $0(0)$ & $7(100)$ & \\
\hline Alcohol consumption & & & & 0.497 & & & 0.900 \\
\hline Yes & $\begin{array}{l}1515 \\
(14.4)\end{array}$ & $4(0.3)$ & $\begin{array}{l}1511 \\
(99.7)\end{array}$ & & $2(0.1)$ & $\begin{array}{l}1513 \\
(99.9)\end{array}$ & \\
\hline No & $\begin{array}{l}8977 \\
(85.3)\end{array}$ & $21(0.2)$ & $\begin{array}{l}8956 \\
(99.8)\end{array}$ & & $10(0.1)$ & $\begin{array}{l}8967 \\
(99.9)\end{array}$ & \\
\hline Surgery & & & & 0.939 & & & 0.512 \\
\hline Yes & $\begin{array}{l}6637 \\
(63.3)\end{array}$ & $16(0.2)$ & $\begin{array}{l}6621 \\
(99.8)\end{array}$ & & $9(0.1)$ & $\begin{array}{l}6628 \\
(99.9)\end{array}$ & \\
\hline & & rag & $13 / 17$ & & & & \\
\hline
\end{tabular}




\begin{tabular}{|c|c|c|c|c|c|c|c|}
\hline No & $\begin{array}{l}3855 \\
(36.7)\end{array}$ & $9(0.2)$ & $\begin{array}{l}3848 \\
(99.8)\end{array}$ & & $3(0.1)$ & $\begin{array}{l}3852 \\
(99.9)\end{array}$ & \\
\hline lization & & & & 0.561 & & & 0.653 \\
\hline Yes & $\begin{array}{l}8456 \\
(80.6)\end{array}$ & $19(0.2)$ & $\begin{array}{l}8437 \\
(99.8)\end{array}$ & & $10(0.1)$ & $\begin{array}{l}8446 \\
(99.9)\end{array}$ & \\
\hline No & $\begin{array}{l}2036 \\
(19.4)\end{array}$ & $6(0.3)$ & $\begin{array}{l}2030 \\
(99.7)\end{array}$ & & $2(0.1)$ & $\begin{array}{l}2034 \\
(99.9)\end{array}$ & \\
\hline sion & & & & 0.703 & & & 0.970 \\
\hline Yes & 1001 (9.5) & $4(0.4)$ & 997 (99.6) & & $1(0.1)$ & $\begin{array}{l}1000 \\
(99.9)\end{array}$ & \\
\hline No & $\begin{array}{l}9395 \\
(89.5)\end{array}$ & $21(0.2)$ & $\begin{array}{l}9374 \\
(99.8)\end{array}$ & & $11(0.1)$ & 9384() & \\
\hline Not know & $95(0.9)$ & $0(0)$ & 95 (100) & & $0(0)$ & 95 (100) & \\
\hline aphthous & & & & 0.732 & & & 0.828 \\
\hline Yes & $130(1.2)$ & $0(0)$ & $130(100)$ & & $0(0)$ & $130(100)$ & \\
\hline No & $\begin{array}{l}10362 \\
(98.8)\end{array}$ & $25(0.2)$ & $\begin{array}{l}10337 \\
(99.8)\end{array}$ & & $12(0.1)$ & $\begin{array}{l}10350 \\
(99.9)\end{array}$ & \\
\hline
\end{tabular}

Hospitalization

Table 2. Comparison of blood and urine analysis based on HBV and HCV statuses. 


\begin{tabular}{|c|c|c|c|c|c|c|}
\hline \multirow[b]{2}{*}{ ariables } & \multicolumn{3}{|l|}{$\mathrm{HBV}$} & \multicolumn{3}{|l|}{$\mathrm{HCV}$} \\
\hline & Positive & Negative & $\begin{array}{l}P \\
\text { value }\end{array}$ & Positive & Negative & $\begin{array}{l}P \\
\text { value }\end{array}$ \\
\hline \multicolumn{7}{|l|}{ lood analysis } \\
\hline $\mathrm{WBC}\left(/ \mathrm{mm}^{3}\right)$ & $6.49 \pm 1.22$ & $7.08 \pm 1.73$ & 0.090 & $6.13 \pm 2.27$ & $7.08 \pm 1.73$ & 0.058 \\
\hline $\mathrm{RBC}\left(\times 1000 / \mathrm{mm}^{3}\right)$ & $4.89 \pm 0.47$ & $4.90 \pm 0.56$ & 0.969 & $4.65 \pm 0.65$ & $4.90 \pm 0.55$ & 0.125 \\
\hline $\mathrm{Hb}(\mathrm{g} / \mathrm{dL})$ & $14.02 \pm 1.47$ & $13.82 \pm 1.57$ & 0.514 & $13.97 \pm 1.82$ & $13.82 \pm 1.57$ & 0.738 \\
\hline Hct (\%) & $41.95 \pm 3.72$ & $41.33 \pm 4.15$ & 0.459 & $41.05 \pm 4.71$ & $41.33 \pm 4.14$ & 0.812 \\
\hline $\operatorname{MCV}(\mathrm{fl})$ & $86.20 \pm 8$ & $84.88 \pm 7.57$ & 0.384 & $88.88 \pm 8.66$ & $84.87 \pm 7.56$ & 0.066 \\
\hline $\mathrm{MCH}(\mathrm{pg})$ & $28.82 \pm 3.27$ & $28.39 \pm 3.05$ & 0.481 & $30.23 \pm 3.42$ & $28.39 \pm 3.05$ & 0.036 \\
\hline $\mathrm{MCHC}(\mathrm{g} / \mathrm{dL})$ & $33.38 \pm 1$ & $33.39 \pm 1.01$ & 0.964 & $33.97 \pm 0.90$ & $33.39 \pm 1.01$ & 0.047 \\
\hline Platelet $\left(/ \mathrm{mm}^{3}\right)$ & $227.92 \pm 65.36$ & $251.91 \pm 59.29$ & 0.043 & $234.75 \pm 74.99$ & $251.90 \pm 59.31$ & 0.317 \\
\hline Lymphocyte \%) & $36.07 \pm 7.12$ & $38.71 \pm 9.23$ & 0.269 & $36.09 \pm 9.42$ & $38.71 \pm 9.22$ & 0.394 \\
\hline Monocyte (\%) & $1.06 \pm 0.29$ & $1.23 \pm 0.70$ & 0.340 & $1.62 \pm 1.19$ & $1.23 \pm 0.70$ & 0.093 \\
\hline Granulocytes (\%) & $62.87 \pm 7.15$ & $60.06 \pm 9.43$ & 0.249 & $62.29 \pm 9.95$ & $60.06 \pm 9.42$ & 0.478 \\
\hline RDWCV (\%) & $12.01 \pm 0.50$ & $12.57 \pm 0.98$ & 0.023 & $12.75 \pm 1.58$ & $12.57 \pm 0.98$ & 0.550 \\
\hline RDWSD (fl) & $41.51 \pm 3.88$ & $42.29 \pm 3.48$ & 0.374 & $45.93 \pm 9.90$ & $42.27 \pm 3.45$ & 0.273 \\
\hline Plateletcrit $(\times 1000 /$ & $0.21 \pm 0.05$ & $0.21 \pm 0.05$ & 0.831 & $0.19 \pm 0.06$ & $0.21 \pm 0.05$ & 0.198 \\
\hline \multicolumn{7}{|l|}{ ) } \\
\hline $\operatorname{MPV}(\mathrm{fl})$ & $8.23 \pm 0.51$ & $8.16 \pm 0.71$ & 0.706 & $8.41 \pm 0.69$ & $8.16 \pm 0.71$ & 0.274 \\
\hline PDW (fl) & $16.23 \pm 1.59$ & $16.70 \pm 1.04$ & 0.072 & $16.88 \pm 1.12$ & $16.70 \pm 1.04$ & 0.574 \\
\hline Glucose (mg/dL) & $102.28 \pm 52.78$ & $104.57 \pm 37.14$ & 0.758 & $95.58 \pm 13.73$ & $104.58 \pm 37.22$ & 0.402 \\
\hline $\mathrm{BUN}(\mathrm{mg} / \mathrm{dL})$ & $14.10 \pm 4.09$ & $13.37 \pm 3.53$ & 0.304 & $14.93 \pm 5.65$ & $13.37 \pm 3.50$ & 0.123 \\
\hline Creatinine (mg/dL) & $0.95 \pm 0.15$ & $0.89 \pm 0.17$ & 0.084 & $0.98 \pm 0.25$ & $0.89 \pm 0.16$ & 0.060 \\
\hline Triglyceride (mg/dL) & $149.12 \pm 236.54$ & $160.31 \pm 102.79$ & 0.815 & $102.25 \pm 42.39$ & $160.37 \pm 103.37$ & 0.052 \\
\hline Cholesterol (mg/dL) & $176.20 \pm 32.35$ & $192.85 \pm 38.98$ & 0.033 & $172.50 \pm 26.75$ & $192.86 \pm 38.97$ & 0.070 \\
\hline $\mathrm{HDL}(\mathrm{mg} / \mathrm{dL})$ & $49.20 \pm 10.25$ & $48.39 \pm 10.99$ & 0.711 & $59.58 \pm 16.59$ & $48.38 \pm 10.97$ & 0.039 \\
\hline $\mathrm{LDL}(\mathrm{mg} / \mathrm{dL})$ & $99.88 \pm 25.21$ & $112.88 \pm 32.07$ & 0.043 & $92.50 \pm 22.20$ & $112.89 \pm 32.05$ & 0.028 \\
\hline LDL:HDL & $2.06 \pm 0.52$ & $2.42 \pm 0.79$ & 0.002 & $1.67 \pm 0.62$ & $2.42 \pm 0.79$ & 0.001 \\
\hline AST (IU/L) & $19.20 \pm 7.82$ & $19.06 \pm 8.43$ & 0.935 & $46.58 \pm 39.00$ & $19.02 \pm 8.25$ & 0.032 \\
\hline $\mathrm{ALT}(\mathrm{IU} / \mathrm{L})$ & $15.72 \pm 8.26$ & $18.82 \pm 13.54$ & 0.253 & $38.25 \pm 27.10$ & $18.77 \pm 13.43$ & 0.030 \\
\hline ALP (IU/L) & $194.00 \pm 52.32$ & $207.03 \pm 59.88$ & 0.277 & $215.75 \pm 55.11$ & $206.98 \pm 59.89$ & 0.612 \\
\hline GGT (IU/L) & $18.37 \pm 6.40$ & $25.05 \pm 20.80$ & 0.108 & $59.17 \pm 73.63$ & $25.00 \pm 20.62$ & 0.136 \\
\hline Vit $D_{3}(\mathrm{ng} / \mathrm{ml})$ & $25.01 \pm 14.88$ & $21.77 \pm 12.39$ & 0.201 & $26.94 \pm 13.97$ & $21.77 \pm 12.40$ & 0.149 \\
\hline \multicolumn{7}{|l|}{ rine analysis } \\
\hline SG & $1.02 \pm 0.01$ & $15.18 \pm 119.12$ & 0.552 & $1.02 \pm 0.01$ & $15.18 \pm 119.14$ & 0.680 \\
\hline $\mathrm{pH}$ & $5.88 \pm 0.89$ & $5.83 \pm 0.88$ & 0.760 & $5.75 \pm 0.75$ & $5.83 \pm 0.88$ & 0.761 \\
\hline Creatinine $(\mathrm{mg} / \mathrm{dL})$ & $134.17 \pm 71.03$ & $140.36 \pm 77.30$ & 0.749 & $136.43 \pm 79.52$ & $140.36 \pm 77.32$ & 0.872 \\
\hline
\end{tabular}


Table 3. Serum level of HBV DNA and HCV RNA.

\begin{tabular}{lll}
\hline Serum levels of virus (copies/ml) & HBV DNA & HCV RNA \\
\hline$<300$ (below LOQ) & $13(52 \%)$ & $0(0)$ \\
$<10^{3}$ & $4(16 \%)$ & $0(0)$ \\
$10^{3}$ to $<10^{4}$ & $5(20 \%)$ & $0(0)$ \\
$10^{4}$ to $<10^{5}$ & $0(0)$ & $1(8.3 \%)$ \\
$10^{5}$ to $<10^{6}$ & $2(8 \%)$ & $7(58.4 \%)$ \\
$10^{6}$ to $<10^{7}$ & $0(0)$ & $3(25 \%)$ \\
$10^{7}$ to $<10^{8}$ & $1(4 \%)$ & $1(8.3 \%)$ \\
$\geq 10^{8}$ & $0(0)$ & $0(0)$ \\
Total & $25(100)$ & $12(100)$ \\
\hline
\end{tabular}

LOQ: limit of quantification.

\section{Figures}

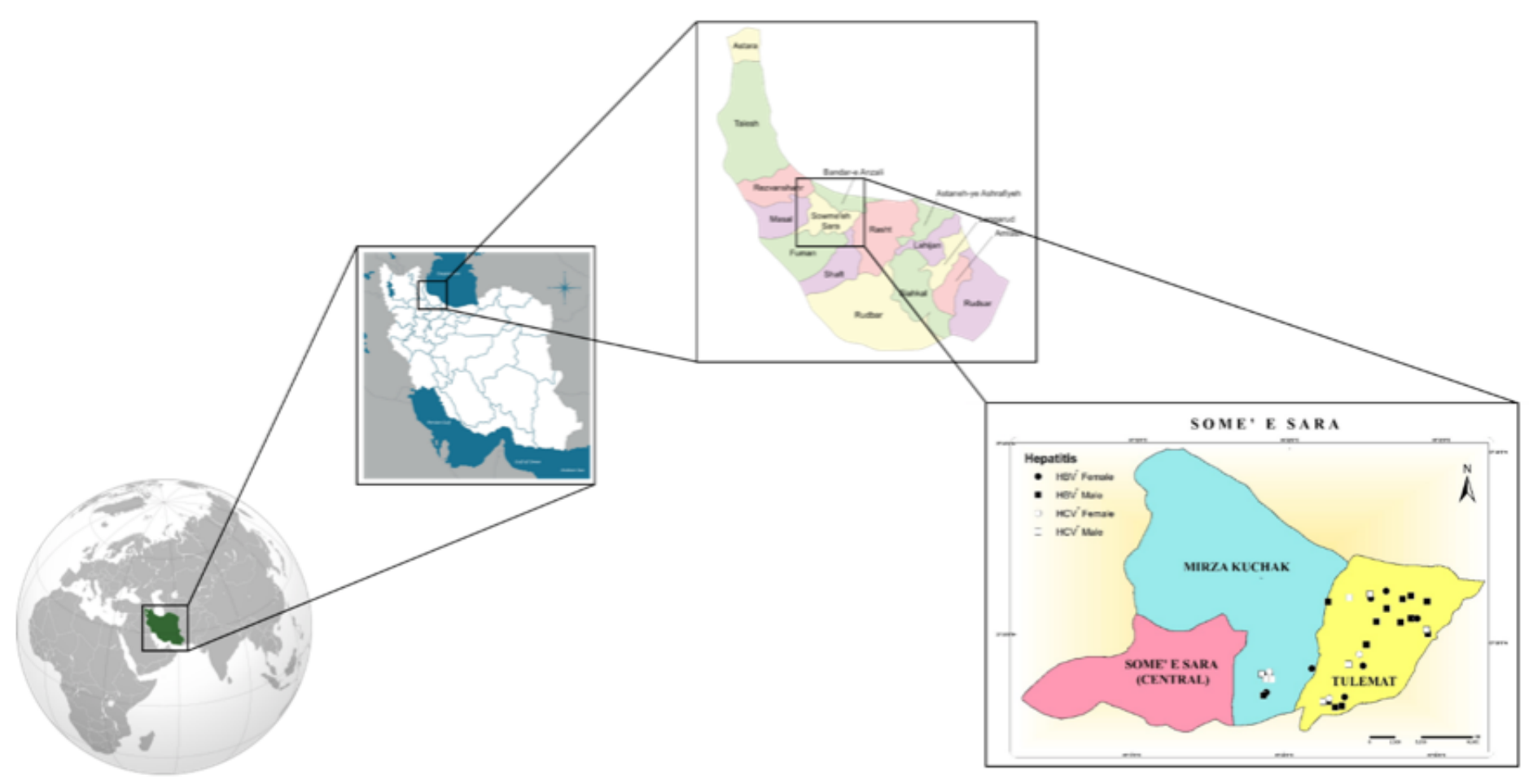

Figure 1

Geographic distribution of patients based on positivity of HBV and HCV and their gender. (The map depicted in figure is our own work) 


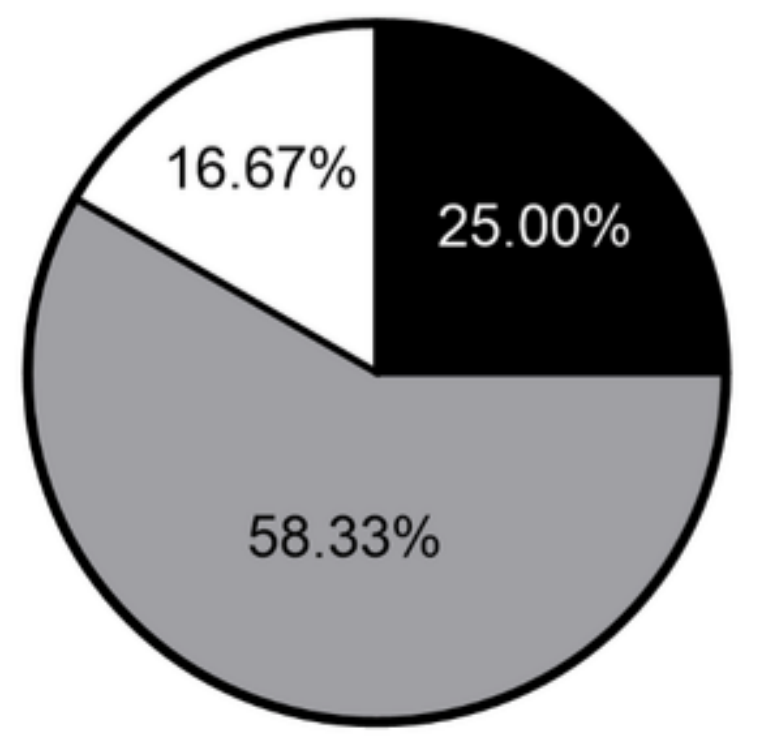

\section{Total $=12$}

\section{Figure 2}

Distribution of HCV genotype in our patients. 